\title{
Basic disturbances in skeletal muscle fatty acid metabolism in obesity and type 2 diabetes mellitus
}

\author{
E. E. Blaak \\ Department of Human Biology, Nutrition and Toxicology Research Institute Maastricht, Maastricht University, \\ PO Box 616, 6200 MD Maastricht, The Netherlands
}

\begin{abstract}
The present article addresses the hypothesis that disturbances in skeletal muscle fatty acid handling in abdominal obesity and type 2 diabetes mellitus may play a role in the aetiology of increased adipose tissue stores, increased triacylglycerol storage in skeletal muscle and skeletal muscle insulin resistance. The uptake and/or oxidation of fatty acids have been shown to be impaired during post-absorptive conditions in abdominally-obese subjects and/or subjects with type 2 diabetes. Also, human studies have shown that muscle of subjects that are (abdominally) obese and/or have type 2 diabetes is characterized by an inability to increase fatty acid uptake and/or fatty acid oxidation during $\beta$-adrenergic stimulation and exercise. This disturbance in fat oxidation may promote, on one hand, the development of increased adipose tissue stores and obesity. On the other hand, fatty acids that are taken up by muscle and not oxidized may increase triacylglycerol storage in muscle, which has been associated with skeletal-muscle insulin resistance. Disturbances in the capacity to increase fat oxidation during post-absorptive conditions, $\beta$-adrenergic stimulation and exercise in subjects who are obese and/or have type 2 diabetes persist after weight reduction, indicating that the diminished fat oxidation may be a primary factor leading to the obese and/or insulin-resistant state rather than an adaptational response. Clearly, the precise sequence of events leading to an increased adiposity and insulin resistance in obesity and type 2 diabetes mellitus is not yet fully understood.
\end{abstract}

Fatty acid metabolism: Skeletal muscle: Obesity: Type 2 diabetes

Obesity and type 2 diabetes mellitus frequently occur together, indicating that these conditions may share common pathological mechanisms. Both conditions are characterized by insulin resistance and are often accompanied by increased circulating concentrations of NEFA, an increased adipose tissue mass and disturbances in skeletal-muscle fatty acid handling. As it has a large total mass and increased energy expenditure during physical activity, skeletal muscle is one of the most important organs involved in NEFA metabolism in healthy human subjects (Dagenais et al. 1976). Recent investigations imply that the use of lipid is inefficient in skeletal muscle of subjects who are obese and/or have type 2 diabetes, a finding that links muscle metabolism to the development or maintenance of the obese state. Also, the potential of muscle to use carbohydrate or lipid fuels and the potential of substrate competition between these fuels have been a major topic of many investigations on muscle insulin resistance. The present article addresses the relationship between muscle lipid handling and obesity and insulin resistance. It is hypothesized that inefficient muscle fatty acid utilization may promote fat storage above oxidation, leading to increased adipose tissue stores and triacylglycerol storage within skeletal muscle, thereby promoting obesity and insulin resistance.

\section{Skeletal muscle fatty acid utilization in obesity}

Several observations in the past decade have suggested that obesity is associated with impaired skeletal muscle fatty acid handling. A diminished capacity to take up fatty acids has been reported in skeletal muscle of obese males during $\beta$-adrenergic stimulation (Blaak et al. 1994) and in viscerally-obese women during post-absorptive conditions (Colberg et al. 1995). This observation was made despite the fact that the obese subjects had neither lower plasma NEFA nor lower rates of systemic appearance of NEFA. Furthermore, skeletal muscle fatty acid oxidation has been shown to be impaired in leg muscle of viscerally-obese

\footnotetext{
Abbreviations: CPT1, carnitine palmitoyltransferase 1; FABPc, cytosolic fatty acid-binding protein; FAT, fatty acid translocase Corresponding author: Dr E. E. Blaak, fax +31 43 3670976, email E.Blaak@HB.Unimaas.nl
} 
subjects during post-absorptive conditions, whereas glucose uptake and glucose oxidation are increased (Colberg et al. 1995). Additionally, studies using intact muscle strips from obese subjects have shown a lowered fat oxidation (as measured by ${ }^{14} \mathrm{CO}_{2}$ production from ${ }^{14} \mathrm{C}$-labelled fatty acids) in obese women (BMI 38.3 (SD $3 \cdot 1) \mathrm{kg} / \mathrm{m}^{2}$; JongYeon et al. 2002), which in a subsequent study has been suggested to be a characteristic of extremely-obese subjects (BMI $53 \cdot 8$ (SD $3 \cdot 5) \mathrm{kg} / \mathrm{m}^{2}$; Hulver et al. 2003). Weight reduction does not improve the impaired capacity to utilize plasma fatty acids in obese subjects during $\beta$-adrenergic stimulation (Blaak et al. 1994) or during post-absorptive conditions (Kelley et al. 1999), suggesting that these defects may be important in the aetiology of obesity by promoting a positive fat balance.

Support for this concept has come from findings that a decreased reliance on lipid oxidation is a risk factor for weight gain in Pima Indians in Arizona (Zurlo et al. 1990). Subjects with a high RQ $(0.877)$ are 2.5 times more likely to gain $\geq 5 \mathrm{~kg}$ than those with a low RQ $(0 \cdot 822)$, even after adjustment for differences in energy balance, adiposity and gender. Additionally, post-obese women show decrements in postprandial and $24 \mathrm{~h}$ fat oxidation as compared with never-obese women, and the value of post-absorptive RQ is positively associated with weight gain after a period of low energy intake (Froidevaux et al. 1993). Also, in postobese women it has been shown that fat oxidation during exercise (at $60-65 \% \mathrm{~V}_{\mathrm{O}_{2} \max }$ ) is subnormal for their high circulating levels of NEFA (Ranneries et al. 1998; Ezell et al. 1999).

Wade et al. (1990) reported a positive relationship between percentage body fat and the RER during exercise in obese subjects, again indicating that the capacity to oxidize fat during exercise is reduced in obesity. However, this finding has been criticized because in this study most subjects were lean (percentage body fat $<25$ ). Also, in this study subjects exercised at a fixed workload of $100 \mathrm{~W}$, which may have disturbed the relationship between fitness and fatness. Indeed, two subsequent studies did not confirm the results of the Wade et al. (1990) study (Geerling et al. 1994; Helge et al. 1999).

A number of recent studies have indicated that it is not only the total capacity to oxidize fat that is impaired during exercise, but that there may also be differences in the source of fatty acids used. Abdominally-obese women have been shown to have an increased utilization of triacylglycerol-derived fatty acids (derived from plasma or intramuscular triacylglycerols) during exercise as compared with normal-weight controls (Horowitz \& Klein, 2000). It is possible that increased triacylglycerol-derived fatty acid oxidation during exercise in obese subjects is driven by the mass of muscle triacylglycerol stores, which have been reported to be increased in obese subjects (Pan et al. 1997; Kelley \& Goodpaster, 2001).

\section{Skeletal muscle fatty acid utilization in type 2 diabetes mellitus}

As indicated earlier, obesity and type 2 diabetes mellitus may share common pathological mechanisms. Indeed, in obese subjects with type 2 diabetes mellitus similar disturbances in skeletal muscle fatty acid handling have been reported to those present in obese subjects. Obese patients with type 2 diabetes also have reduced uptake rates of plasma NEFA by skeletal muscle. This result has been found by using both limb balance studies (Kelley \& Simoneau, 1994; Blaak et al. 2000b; Blaak \& Wagenmakers, 2002) and positron emission tomography to monitor the uptake of fatty acids in the lower extremity muscles of individuals with impaired glucose tolerance (Turpeinen et al. 1999).

Studies using the forearm balance technique in combination with infusion of the stable-isotope tracer $\left[\mathrm{U}_{-}{ }^{13} \mathrm{C}\right]$ palmitate have shown that the uptake and oxidation of NEFA are diminished in skeletal muscle of obese subjects with type 2 diabetes as compared with healthy controls during post-absorptive conditions and during $\beta$-adrenergic stimulation (Blaak et al. 2000b; Blaak \& Wagenmakers, 2002). In addition, in skeletal muscle of control subjects there is a marked release of oxidation products from $\left[{ }^{13} \mathrm{C}\right]$ palmitate in the form of ${ }^{13} \mathrm{CO}_{2}\left(15 \%\right.$ of the ${ }^{13} \mathrm{C}$ uptake from labelled palmitate), from which it can be calculated that about $50 \%$ of the fatty acids taken up by forearm muscle are directly oxidized during $\beta$-adrenergic stimulation. In subjects with type 2 diabetes there is no detectable release of ${ }^{13} \mathrm{CO}_{2}$, despite a marked uptake of the ${ }^{13} \mathrm{C}$ label as [U- ${ }^{13} \mathrm{C}$ ]palmitate (60\% of the control value; Fig. 1). These data indicate that the fatty acids taken up by muscle are not converted to oxidation products in muscles of subjects with type 2 diabetes. The most likely alternative fate of the tracer in subjects with type 2 diabetes is synthesis of triacylglycerols and incorporation into the muscle triacylglycerol stores. As an increased glycerol release has also been found in these subjects both during baseline conditions and during $\beta$-adrenergic stimulation (Blaak et al. $2000 \mathrm{~b}$ ), the implication is that the triacylglycerol turnover rate is higher in the diabetic subjects. Thus, it is also possible that the $\left[\mathrm{U}^{13}{ }^{13} \mathrm{C}\right]$ palmitate tracer is diluted to a larger extent in the intramuscular triacylglycerol and NEFA pool in subjects with type 2 diabetes as compared with controls. This difference implies that the diabetic subjects and healthy controls differ in the fat sources that are oxidized in these conditions.

Disturbed muscle lipid handling in diabetes has also been demonstrated by Kelley \& Simoneau (1994), who have shown diminished fat oxidation in the post-absorptive state in subjects with type 2 diabetes mellitus. Furthermore, despite the reduced fat oxidation in the post-absorptive state, obese individuals and those with type 2 diabetes mellitus manifest an impaired suppression of NEFA uptake (Kelley \& Simoneau, 1994) and a higher lipid oxidation in leg muscle during insulin-stimulated conditions (Kelley \& Mandarino, 2000). Healthy muscle switches from predominantly lipid oxidation in fasting conditions to an increased glucose uptake and oxidation in postprandial conditions, with a suppression of lipid oxidation. On the basis of their findings, Kelley \& Mandarino (2000) have hypothesized that the capacity of muscle to switch between fuels is lost in insulin resistance (metabolic inflexibility) and speculated that this mechanism may play an important role in the lipid accumulation within the insulin-resistant muscle. 
(a)

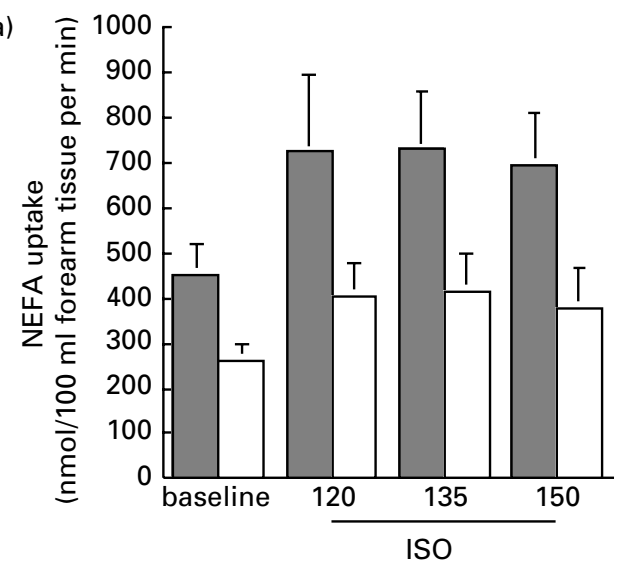

(b)

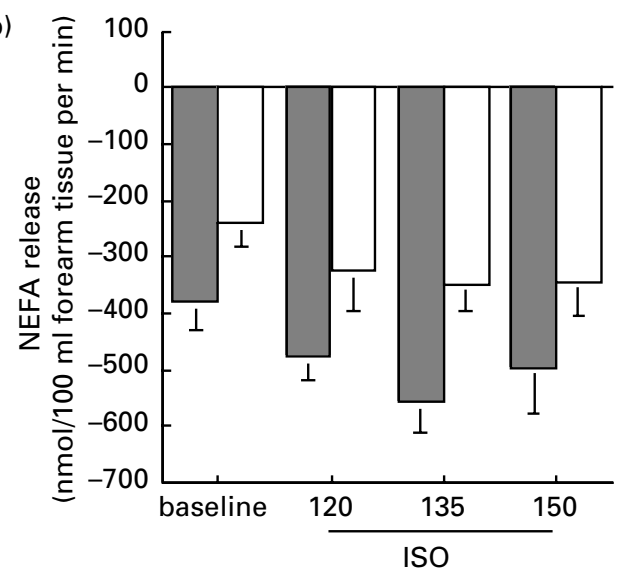

(c)

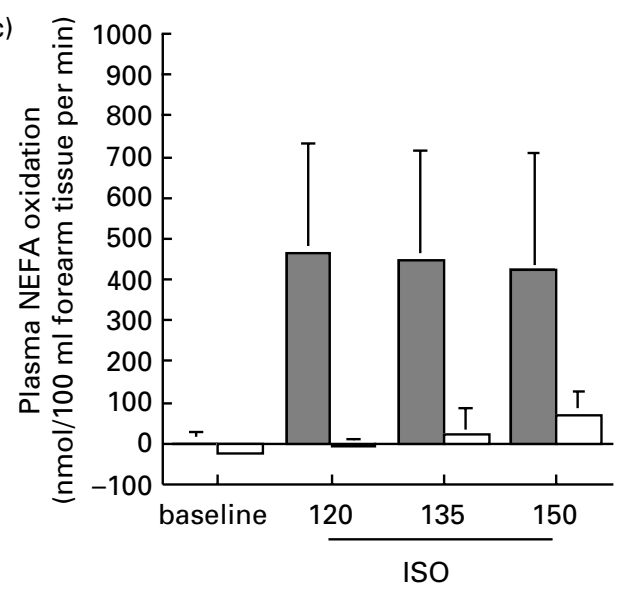

Fig. 1. Skeletal muscle fatty acid (NEFA) uptake (a), release (b) and plasma NEFA oxidation (c) in skeletal muscle of eight subjects with type 2 diabetes $(\square)$ and eight control subjects $(\square)$ during baseline conditions and during infusion of the non-selective $\beta$-agonist isoprenaline (ISO). Values are means with their standard errors represented by vertical bars. (Adapted from Blaak et al. 2000b.)

It has been shown that obese subjects with type 2 diabetes have a diminished plasma NEFA oxidation and a higher triacylglycerol-derived fatty acid oxidation as compared with obese control subjects during moderateintensity exercise $\left(50 \% \mathrm{~V}_{\mathrm{O}_{2} \text { max }}\right.$; Blaak et al. 2000a). This

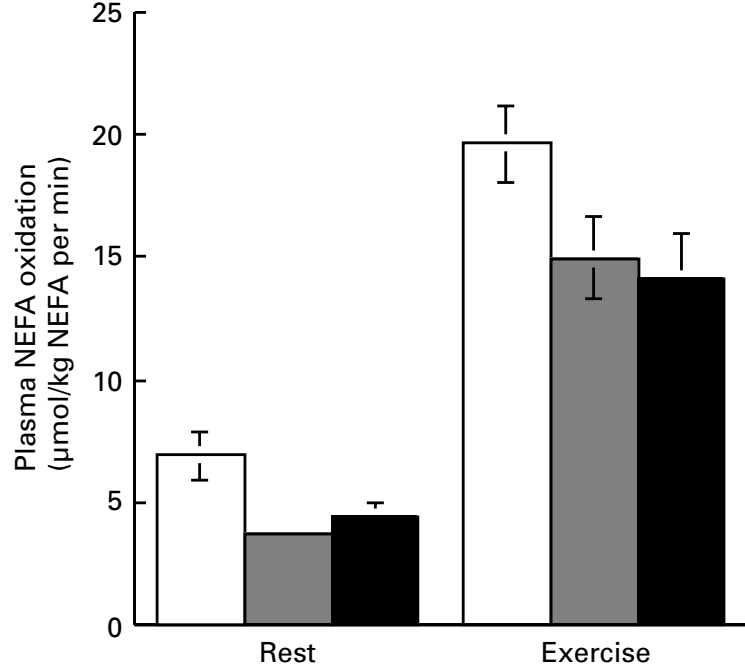

Fig. 2. Plasma fatty acid oxidation in seven obese subjects ( $\square$ ), seven obese subjects with impaired glucose tolerance $(\square)$ and seven obese subjects with type 2 diabetes ( $\boldsymbol{\square}$ ) at rest and during exercise. Values are means with their standard errors represented by vertical bars. At rest the differences between groups were significant $(P<0.01)$. During exercise the differences between groups tended to be significant $(P=0 \cdot 07)$. (Adapted from Mensink et al. 2001.)

finding indicates that the disturbed fatty acid utilization in the post-absorptive state and $\beta$-adrenergically-stimulated conditions also extends to the condition of physical exercise. It should be noted that in this study the lowered plasma-derived fatty acid oxidation occurred in the presence of an unchanged total fat oxidation and a slightly increased triacylglycerol-derived fatty acid oxidation. This finding appears to be consistent with those observed in abdominally-obese subjects during exercise, showing that while the capacity for plasma fatty acid oxidation seems to be reduced, total fat oxidation may be normal or even increased (Horowitz \& Klein, 2000), possibly as a result of a mass action effect of increased NEFA delivery from intramuscular triacylglycerol sources or plasma triacylglycerols.

The impaired capacity to oxidize plasma fatty acids during exercise persists after weight reduction in subjects with type 2 diabetes (Blaak et al. 2001) and is already present in obese subjects with impaired glucose tolerance (Turpeinen et al. 1999; Mensink et al. 2001; Fig. 2), indicating that this lowered fat utilization during postabsorptive conditions or during exercise may play a primary role in the transition of impaired glucose tolerance into type 2 diabetes mellitus. It has been shown in a recent study that lifestyle intervention (a combined diet-physical activity intervention) can prevent a further deterioration of disturbances in plasma NEFA oxidation in subjects with impaired glucose tolerance (M Mensink, E Blaak, W Saris and A Wagenmakers, unpublished results), suggesting that the inclusion of physical activity into the programme is able to compensate for the impaired ability to oxidize fat. It can be speculated that this compensation process may be one of the mechanisms underlying the previously-reported beneficial effects of this type of lifestyle intervention 
programme, addressing diet and exercise, on glucose tolerance and insulin resistance (Tuomilehto et al. 2001; Mensink et al. 2003b).

In summary, both (visceral) obesity and type 2 diabetes are characterized by disturbances in skeletal muscle fatty acid handling. During post-absorptive conditions, $\beta$-adrenergic stimulation and exercise fatty acid uptake and/or oxidation appear to be diminished, whereas during insulin-mediated (postprandial) conditions there are indications of an impaired ability to suppress muscle fatty acid uptake and muscle fatty acid oxidation. Weight reduction does not seem to improve skeletal muscle fatty acid oxidation during $\beta$-adrenergic stimulation, post-absorptive conditions or exercise in subjects who are obese and/or have type 2 diabtetes, indicating that the blunted capacity to increase fat oxidation under conditions with a relatively high lipolytic rate may be a primary impairment in the aetiology of obesity and insulin resistance rather than an adaptational response.

\section{Skeletal muscle lipolysis}

In addition to the lowered capacity to oxidize fatty acids, disturbances in the regulation of skeletal muscle lipolysis may also contribute to the increased lipid accumulation in skeletal muscle. So far, little is known about the regulation of skeletal muscle lipolysis. It has been shown that hormone-sensitive lipase is also expressed in myocytes (Langfort et al. 1999) and that hormone-sensitive lipase can be activated by adrenaline and by muscle contraction (Langfort et al. 1998) and may be regulated in parallel by $\beta$-adrenergic stimulation and contraction-related factors during exercise (Watt et al. 2003). Although it seems plausible that the key mechanisms involved in the regulation of the catecholamine-mediated lipolysis in skeletal muscle are the same as those in adipocytes, there are some recent data indicating that interstitial glycerol, as studied by the microdialysis technique, is regulated differently in adipose tissue as compared with muscle by both insulin and $\beta$-adrenergic stimulation (Stumvoll et al. 2000; HagstromToft et al. 2001). Recent studies (E Blaak, S Schiffelers, W Saris, M Mensink and E Kooi, unpublished results) have indicated that obesity is accompanied by a blunted capacity to increase muscle lipolysis (as reflected by an increase in interstitial glycerol; Fig. 3) during in situ $\beta_{2}$-adrenergic stimulation, suggesting a role for defects in the regulation of skeletal muscle lipolysis in the excessive muscle triacylglycerol storage. So far, it is not known whether this disturbed muscle lipolysis also extends to type 2 diabetes.

\section{Underlying mechanisms for disturbed muscle fatty acid oxidation}

\section{Fatty acid uptake}

As indicated earlier, obese subjects and subjects with type 2 diabetes may have reduced efficiency for plasma fatty acid uptake under conditions with a high lipolytic rate (post-absorptive conditions, $\beta$-adrenergic stimulation and exercise), which may be a contributing factor to a reduced
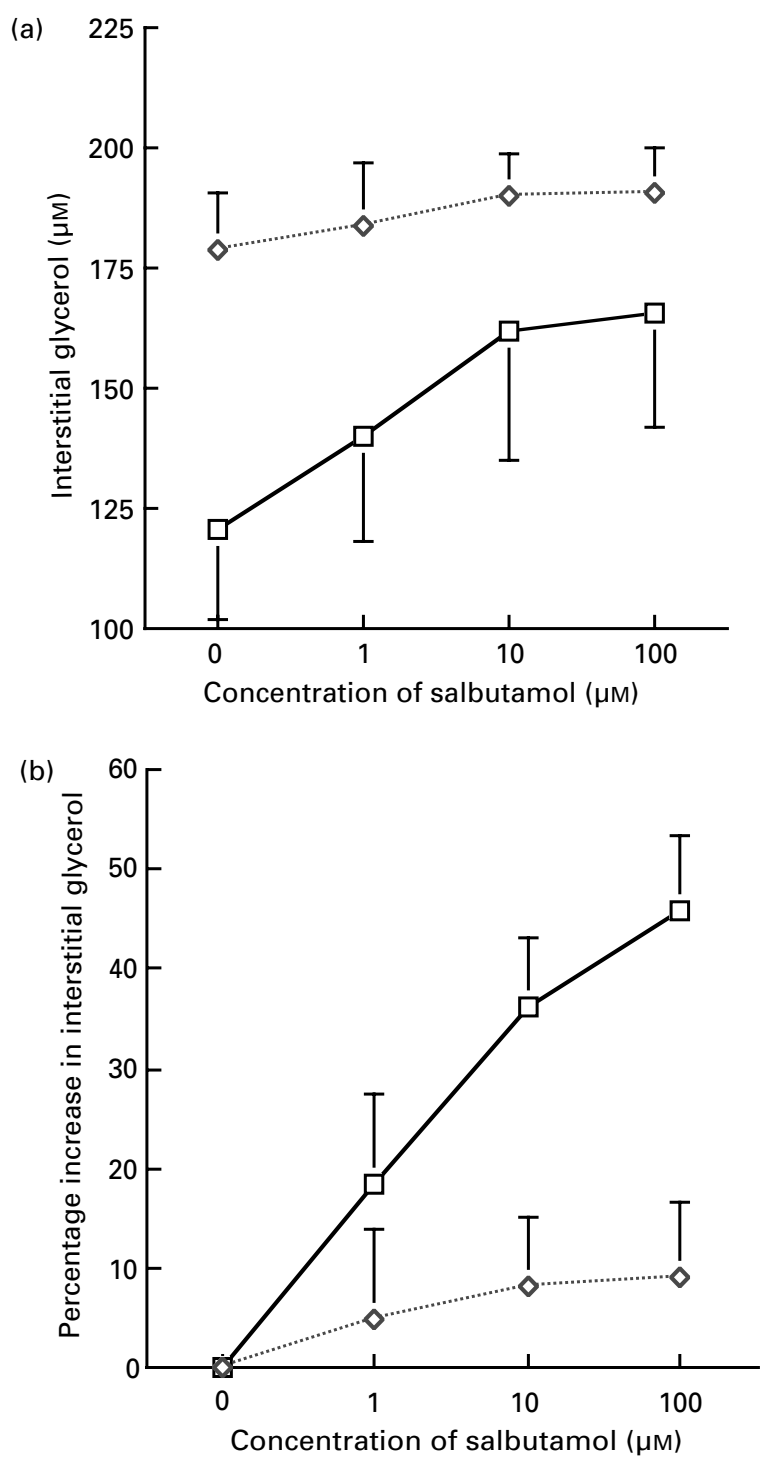

Fig. 3. Effect of local administration of the $\beta_{2}$-adrenoceptor agonist salbutamol on interstitial glycerol concentration (as studied by microdialysis; a) and percentage increase in glycerol (b) in skeletal muscle (gastrocnemius) of eight obese ( $\square-\square$ ) and eight lean $(\diamond \cdots \diamond)$ subjects. Values are means with their standard errors represented by vertical bars. Two-way repeated measures ANOVA: repeated measures $P<0.001$; group $P<0.05$.

fatty acid oxidation. Plasma concentrations of NEFA play an important role in determining the rate of NEFA uptake into tissues, but are not the only factor. Fatty acid uptake by skeletal muscle most probably occurs via both diffusion and protein-mediated transport of NEFA (Glatz et al. 2001a,b). A number of proteins have been identified as putative fatty acid transporters in skeletal muscle, i.e. cytosolic fatty acid-binding protein (FABPc), fatty acid translocase (FAT)/CD36, plasma membrane fatty acidbinding protein and fatty acid transport protein, but their role in the regulation of fat metabolism remains unclear. In a study by Simoneau et al. (1999), the content of FABPc has been found to be normal and that of sarcolemmal fatty acid-binding protein increased in muscle biopsies from 
obese subjects with normal glucose tolerance as compared with healthy controls. Furthermore, studies by Blaak et al. $(2000 b)$ have shown a lowered NEFA uptake and lowered FABPc protein content in muscle of subjects with type 2 diabetes as compared with that of lean control subjects. However, it has been shown that FABPc is present in relative excess in muscle and plays a substantial but merely permissive role in fatty acid uptake by skeletal muscles (Glatz et al. 2003), indicating that a diminished content of FABPc is probably not rate limiting for plasma NEFA utilization by the muscle. Interestingly, a mutation in the FAT/CD36 gene has been associated with a defective fatty acid metabolism and hypertriacylglycerolaemia in the spontaneously-hypertensive rat (Aitman et al. 1999), and FAT/CD36 deficiency has been associated with functionally important impairment of fatty acid transport in muscle and adipose tissue (Coburn et al. 2000; Hajri et al. 2001). Support for an important role for fatty acid transport proteins in disturbed fatty acid handling has come from a recent study in which it was shown that the proteinmediated component of fatty acid transport is reduced in human diabetic muscle cells and can be improved by thiazolidinedione treatment (rosiglitazone, troglitazone and pioglitazone) in concert with an increased FAT/CD36 expression (Wilmsen et al. 2003). Unfortunately, in this study no distinction is made between the FAT/CD36 present in the sarcolemma and in an intracellular (endosomal) pool; FAT/CD36 may be redistributed towards the sarcolemma as a result of muscle contraction (Luiken et al. 2003) or insulin stimulation (Luiken et al. 2002b) with a concomitant increase in the rate of muscular fatty acid uptake.

Moreover, studies with streptozotocin-induced diabetic rats showed that fatty acid transport (as determined with giant vesicles) and plasma membrane FAT/CD36 expression are increased rather than diminished (Luiken et al. 2002a). Additionally, there are indications that fatty acid transport is up regulated in skeletal muscle of obese Zucker rats (Luiken et al. 2001) and that FAT/CD36 translocation to the plasma membrane may be increased in muscle strips of obese subjects and subjects with diabetes (A Bonen, personal communication). These findings may suggest that the lowered uptake of plasma fatty acids observed in obese subjects and obese subjects with type 2 diabetes in in vivo limb balance studies (Blaak et al. 1994, 2000b; Kelley \& Simoneau, 1994; Colberg et al. 1995; Blaak \& Wagenmakers, 2002) and using positron emission tomography scanning (Turpeinen et al. 1999) cannot be explained by a diminished content or translocation of fatty acid transporters, but may be rather secondary to other mechanisms that control the exchange of fatty acids across the muscle membrane.

In this context, it has been shown that the concentration gradient of NEFA between blood and muscle is one of the primary determinants of plasma NEFA uptake and oxidation (van der Vusse et al. 2002). A higher forearm lipolysis has been observed (as indicated by glycerol release) in the muscle of subjects with type 2 diabetes during postabsorptive conditions and during $\beta$-adrenergic stimulation, whereas NEFA release is reduced (Blaak et al. 2000b). It has, therefore, been hypothesized that an increase in forearm lipolysis may lead to an increase in the muscle NEFA concentration and thus reduce the blood-tissue NEFA concentration gradient, thereby inhibiting NEFA uptake. To date, it is not known whether intramuscular NEFA concentrations are increased in obesity and diabetes.

There are increasing indications that a reduced fractional extraction is not the only mechanism that determines fat oxidation. Other factors intrinsic to muscle may also contribute to the decreased fatty acid oxidation and increased storage of fat within muscle.

\section{Mitochondrial transport}

A step that may possibly be rate limiting for (long-chain) fatty acid oxidation is the transport of fatty acids into the mitochondria by means of carnitine palmitoyltransferase 1 (CPT1). An increased content of malonyl-CoA, as a result of dysregulation by acteyl-CoA carboxylase and malonylCoA decarboxylase, can lead to inhibition of CPT1 and subsequently lower fatty acid oxidation. An increased content of malonyl-CoA has been reported in rodent models of obesity and insulin resistance in conjunction with hyperglycaemia and hyperinsulinaemia and reduced lipid oxidation (Saha et al. 1997). Interestingly, a concept has emerged that substrate competition might not only operate in the direction of lipid-induced insulin resistance (as originally described by Randle, 1998), but that a subnormal fat oxidation may result from the glucose-induced inhibition of fatty acid oxidation (a reverse Randle cycle, in which the intracellular glucose availability regulates fatty acid oxidation; Sidossis \& Wolfe, 1996). Superimposed on this regulatory effect of glucose availability may be the mass action effect of NEFA availability. Indeed, skeletal muscle glucose oxidation has been reported to be higher in obese insulin-resistant subjects and subjects with type 2 diabetes during post-absorptive conditions (Kelley et al. 1999) and during $\beta$-adrenergic stimulation (Blaak et al. 1994), and this situation does not change as a result of weight loss (Blaak et al. 1994; Kelley et al. 1999). In addition, Mandarino et al. (1996) have shown that at comparable arterial glucose concentration and higher NEFA concentrations leg glucose uptake and oxidation are higher in obese subjects compared with lean subjects. Interestingly, a recent study in human skeletal muscle has shown that a combination of hyperglycaemia and hyperinsulinaemia increases malonyl-CoA, inhibits functional CPT1 activity and shunts long-chain fatty acids away from oxidation and towards storage in human muscle (Rasmussen et al. 2002), indicating that this proposed concept of 'reverse' substrate competition may be operative in human muscle. Additionally, two recent studies have shown that an improvement in fat oxidation as a result of training (Schrauwen et al. 2002) or lifestyle intervention (Mensink et al. 2003a) is accompanied by decreased acetyl-CoA carboxylase mRNA expression, suggesting that a lowered inhibition of mitochondrial fatty acid transport through malonyl-CoA may have contributed to the improved fat oxidative capacity. Thus, there are strong indications that a lowered mitochondrial transport through CPT1 may contribute to the reduced fat oxidation in the muscle of subjects who are obese and/or have type 2 diabetes. 
A recent study looking at fat oxidation in muscle strips of obese and lean subjects has shown that, in addition to defects at CPT1, disturbances downstream of CPT1 (such as mitochondrial content) also contribute to the reduced reliance on lipid oxidation in human skeletal muscle in obesity (Kim et al. 2000).

\section{Conclusion}

The role of skeletal muscle glucose and lipid substrate competition in the development of insulin resistance has been the topic of many investigations. Several years ago, Randle (1998) hypothesized that excessive fat oxidation in skeletal muscle interferes with insulin-mediated glucose uptake by muscle cells through an inhibition of pyruvate dehydrogenase. Studies of several investigators support the concept of the effect of elevated NEFA concentration on glucose metabolism during insulin-mediated conditions, although the post-receptor mechanisms involved may argue against the Randle cycle, as originally proposed (Roden et al. 1996; Boden et al. 2001). At present, there is increasing evidence that insulin resistance of muscle in obesity and type 2 diabetes mellitus is characterized by a lowered ability to oxidize fatty acids taken up during postabsorptive conditions, during exercise or during catecholamine stimulation, i.e. during conditions with a relatively high lipolytic rate. Weight reduction does not seem to improve skeletal muscle fatty acid oxidation during $\beta$-adrenergic stimulation (Blaak et al. 1994) or postabsorptive conditions in obese subjects (Kelley et al. 1999) or during exercise in obese subjects with type 2 diabetes (Blaak et al. 2001). Thus, this disturbance in fat oxidation may be a primary factor leading to the development of increased adipose tissue stores and obesity. Fatty acids that are taken up by muscle and not oxidized may also increase triacylglycerol storage in muscle, which has been associated with skeletal muscle insulin resistance (Pan et al. 1997; Kelley \& Goodpaster, 2001). It is proposed that underlying mechanisms for the reduced muscle fat oxidation during post-absorptive conditions and catecholamine-stimulated conditions ( $\beta$-adrenergic stimulation, exercise) may be related to disturbances in fatty acid transport capacity, a glucose-induced inhibition of mitochondrial fatty acid transport (through an inhibition of CPT1) and/or disturbances downstream of CPT1 (such as a reduced mitochondrial content).

Based on these observations an important direction for future research is to obtain more information on the capacity of muscle for lipid utilization in obesity and type 2 diabetes, how this capacity is affected by body fat distribution and the extent of adiposity, and to what extent there is compensation for this defect once the obese and/or diabetic state has developed.

\section{References}

Aitman TJ, Glazier AM, Wallace CA, Cooper LD, Norsworthy PJ, Wahid FN, et al. (1999) Identification of Cd36 (fat) as an insulin-resistance gene causing defective fatty acid and glucose metabolism in hypertensive rats. Nature Genetics 21, 76-83.
Blaak EE, van Aggel-Leijssen DP, Wagenmakers AJ, Saris WH \& van Baak MA (2000a) Impaired oxidation of plasma-derived fatty acids in type 2 diabetic subjects during moderate-intensity exercise. Diabetes 49, 2102-2107.

Blaak EE, Van Baak MA, Kemerink GJ, Pakbiers MT, Heidendal GA \& Saris WH (1994) beta-Adrenergic stimulation of skeletal muscle metabolism in relation to weight reduction in obese men. American Journal of Physiology 267, E316-E322.

Blaak EE \& Wagenmakers AJ (2002) The fate of [U-(13)C] palmitate extracted by skeletal muscle in subjects with type 2 diabetes and control subjects. Diabetes 51, 784-789.

Blaak EE, Wagenmakers AJ, Glatz JF, Wolffenbuttel BH, Kemerink GJ, Langenberg CJ, Heidendal GA \& Saris WH (2000b) Plasma FFA utilization and fatty acid-binding protein content are diminished in type 2 diabetic muscle. American Journal of Physiology 279, E146-E154.

Blaak EE, Wolffenbuttel BH, Saris WH, Pelsers MM \& Wagenmakers AJ (2001) Weight reduction and the impaired plasmaderived free fatty acid oxidation in type 2 diabetic subjects. Journal of Clinical Endocrinology and Metabolism 86, $1638-1644$

Boden G, Lebed B, Schatz M, Homko C \& Lemieux S (2001) Effects of acute changes of plasma free fatty acids on intramyocellular fat content and insulin resistance in healthy subjects. Diabetes 50, 1612-1617.

Coburn CT, Knapp FF Jr, Febbraio M, Beets AL, Silverstein RL \& Abumrad NA (2000) Defective uptake and utilization of long chain fatty acids in muscle and adipose tissues of CD36 knockout mice. Journal of Biological Chemistry 275, 32523-32529.

Colberg SR, Simoneau JA, Thaete FL \& Kelley DE (1995) Skeletal muscle utilization of free fatty acids in women with visceral obesity. Journal of Clinical Investigation 95, 1846-1853.

Dagenais GR, Tancredi RG \& Zierler KL (1976) Free fatty acid oxidation by forearm muscle at rest, and evidence for an intramuscular lipid pool in the human forearm. Journal of Clinical Investigation 58, 421-431.

Ezell DM, Geiselman PJ, Anderson AM, Dowdy ML, Womble LG, Greenway FL \& Zachwieja JJ (1999) Substrate oxidation and availability during acute exercise in non-obese, obese, and post-obese sedentary females. International Journal of Obesity and Related Metabolic Disorders 23, 1047-1056.

Froidevaux F, Schutz Y, Christin L \& Jequier E (1993) Energy expenditure in obese women before and during weight loss, after refeeding, and in the weight-relapse period. American Journal of Clinical Nutrition 57, 35-42.

Geerling BJ, Alles MS, Murgatroyd PR, Goldberg GR, Harding M \& Prentice AM (1994) Fatness in relation to substrate oxidation during exercise. International Journal of Obesity and Related Metabolic Disorders 18, 453-459.

Glatz JF, Luiken JJ \& Bonen A (2001a) Involvement of membrane-associated proteins in the acute regulation of cellular fatty acid uptake. Journal of Molecular Neuroscience 16, 123-132.

Glatz JF, Luiken JJ \& Bonen A (2001b) Involvement of membrane-associated proteins in the acute regulation of cellular fatty acid uptake: discussion. Journal of Molecular Neuroscience 16, 151-157.

Glatz JF, Schaap FG, Binas B, Bonen A, van der Vusse GJ \& Luiken JJ (2003) Cytoplasmic fatty acid-binding protein facilitates fatty acid utilization by skeletal muscle. Acta Physiologica Scandinavica 178, 367-371.

Hagstrom-Toft E, Thorne A, Reynisdottir S, Moberg E, Rossner S, Bolinder J \& Arner P (2001) Evidence for a major role of skeletal muscle lipolysis in the regulation of lipid oxidation during caloric restriction in vivo. Diabetes 50, 1604-1611. 
Hajri T, Ibrahimi A, Coburn CT, Knapp FF Jr, Kurtz T, Pravenec M \& Abumrad NA (2001) Defective fatty acid uptake in the spontaneously hypertensive rat is a primary determinant of altered glucose metabolism, hyperinsulinemia, and myocardial hypertrophy. Journal of Biological Chemistry 276, 23661-23666.

Helge JW, Fraser AM, Kriketos AD, Jenkins AB, Calvert GD, Ayre KJ \& Storlien LH (1999) Interrelationships between muscle fibre type, substrate oxidation and body fat. International Journal of Obesity and Related Metabolic Disorders 23, 986-991.

Horowitz JF \& Klein S (2000) Oxidation of nonplasma fatty acids during exercise is increased in women with abdominal obesity. Journal of Applied Physiology 89, 2276-2282.

Hulver MW, Berggren JR, Cortright RN, Dudek RW, Thompson RP, Pories WJ, MacDonald KG, Cline GW, Shulman GI, Dohm GL \& Houmard JA (2003) Skeletal muscle lipid metabolism with obesity. American Journal of Physiology 284, E741-E747.

Jong-Yeon K, Hickner RC, Dohm GL \& Houmard JA (2002) Long- and medium-chain fatty acid oxidation is increased in exercise-trained human skeletal muscle. Metabolism 51, 460-464.

Kelley DE \& Goodpaster BH (2001) Skeletal muscle triglyceride. An aspect of regional adiposity and insulin resistance. Diabetes Care 24, 933-941.

Kelley DE, Goodpaster B, Wing RR \& Simoneau JA (1999) Skeletal muscle fatty acid metabolism in association with insulin resistance, obesity, and weight loss. American Journal of Physiology 277, E1130-E1141.

Kelley DE \& Mandarino LJ (2000) Fuel selection in human skeletal muscle in insulin resistance: a re-examination. Diabetes 49, 677-683.

Kelley DE \& Simoneau JA (1994) Impaired free fatty acid utilization by skeletal muscle in non-insulin-dependent diabetes mellitus. Journal of Clinical Investigation 94, 2349-2356.

Kim JY, Hickner RC, Cortright RL, Dohm GL \& Houmard JA (2000) Lipid oxidation is reduced in obese human skeletal muscle. American Journal of Physiology 279, E1039-E1044.

Langfort J, Ploug T, Ihlemann J, Enevoldsen LH, Stallknecht B, Saldo M, Kjaer M, Holm C \& Galbo H (1998) Hormonesensitive lipase (HSL) expression and regulation in skeletal muscle. Advances in Experimental Medicine and Biology 441, 219-228.

Langfort J, Ploug T, Ihlemann J, Saldo M, Holm C \& Galbo H (1999) Expression of hormone-sensitive lipase and its regulation by adrenaline in skeletal muscle. Biochemical Journal 340, 459-465.

Luiken JJ, Arumugam Y, Bell RC, Calles-Escandon J, Tandon NN, Glatz JF \& Bonen A (2002a) Changes in fatty acid transport and transporters are related to the severity of insulin deficiency. American Journal of Physiology 283, E612-E621.

Luiken JJ, Arumugam Y, Dyck DJ, Bell RC, Pelsers MM, Turcotte LP, Tandon NN, Glatz JF \& Bonen A (2001) Increased rates of fatty acid uptake and plasmalemmal fatty acid transporters in obese Zucker rats. Journal of Biological Chemistry 276, 40567-40573.

Luiken JJ, Coort SL, Willems J, Coumans WA, Bonen A, van der Vusse GJ \& Glatz JF (2003) Contraction-induced fatty acid translocase/CD36 translocation in rat cardiac myocytes is mediated through AMP-activated protein kinase signaling. Diabetes 52, 1627-1634.

Luiken JJ, Dyck DJ, Han XX, Tandon NN, Arumugam Y, Glatz JF \& Bonen A (2002b) Insulin induces the translocation of the fatty acid transporter FAT/CD36 to the plasma membrane. American Journal of Physiology 282, E491-E495.
Mandarino LJ, Consoli A, Jain A \& Kelley DE (1996) Interaction of carbohydrate and fat fuels in human skeletal muscle: impact of obesity and NIDDM. American Journal of Physiology 270, E463-E470.

Mensink M, Blaak EE, van Baak MA, Wagenmakers AJ \& Saris WH (2001) Plasma free fatty acid uptake and oxidation are already diminished in subjects at high risk for developing type 2 Diabetes. Diabetes 50, 2548-2554.

Mensink M, Blaak EE, Vidal H, De Bruin TW, Glatz JF \& Saris WH (2003a) Lifestyle changes and lipid metabolism gene expression and protein content in skeletal muscle of subjects with impaired glucose tolerance. Diabetologia 46, 1082-1089.

Mensink M, Corpeleijn E, Feskens EJ, Kruijshoop M, Saris WH, de Bruin TW \& Blaak EE (2003b) Study on lifestyleintervention and impaired glucose tolerance Maastricht (SLIM): design and screening results. Diabetes Research and Clinical Practice 61, 49-58.

Pan DA, Lillioja S, Kriketos AD, Milner MR, Baur LA, Bogardus C, Jenkins AB \& Storlien LH (1997) Skeletal muscle triglyceride levels are inversely related to insulin action. Diabetes 46, 983-988.

Randle PJ (1998) Regulatory interactions between lipids and carbohydrates: the glucose fatty acid cycle after 35 years. Diabetes/Metabolism Reviews 14, 263-283.

Ranneries C, Bulow J, Buemann B, Christensen NJ, Madsen J \& Astrup A (1998) Fat metabolism in formerly obese women. American Journal of Physiology 274, E155-E161.

Rasmussen BB, Holmback UC, Volpi E, Morio-Liondore B, Paddon-Jones D \& Wolfe RR (2002) Malonyl coenzyme A and the regulation of functional carnitine palmitoyltransferase-1 activity and fat oxidation in human skeletal muscle. Journal of Clinical Investigation 110, 1687-1693.

Roden M, Price TB, Perseghin G, Petersen KF, Rothman DL, Cline GW \& Shulman GI (1996) Mechanism of free fatty acidinduced insulin resistance in humans. Journal of Clinical Investigation 97, 2859-2865.

Saha AK, Vavvas D, Kurowski TG, Apazidis A, Witters LA, Shafrir E \& Ruderman NB (1997) Malonyl-CoA regulation in skeletal muscle: its link to cell citrate and the glucose-fatty acid cycle. American Journal of Physiology 272, E641-E648.

Schrauwen P, van Aggel-Leijssen DP, Hul G, Wagenmakers AJ, Vidal H, Saris WH \& van Baak MA (2002) The effect of a 3-month low-intensity endurance training program on fat oxidation and acetyl-CoA carboxylase-2 expression. Diabetes 51, 2220-2226.

Sidossis LS \& Wolfe RR (1996) Glucose and insulin-induced inhibition of fatty acid oxidation; the glucose-fatty acid cycle reversed. American Journal of Physiology 270, E733-E738.

Simoneau JA, Veerkamp JH, Turcotte LP \& Kelley DE (1999) Markers of capacity to utilize fatty acids in human skeletal muscle: relation to insulin resistance and obesity and effects of weight loss. FASEB Journal 13, 2051-2060.

Stumvoll M, Jacob S, Wahl HG, Hauer B, Loblein K, Grauer P, Becker R, Nielsen M, Renn W \& Haring H (2000) Suppression of systemic, intramuscular, and subcutaneous adipose tissue lipolysis by insulin in humans. Journal of Clinical Endocrinology and Metabolism 85, 3740-3745.

Tuomilehto J, Lindstrom J, Eriksson JG, Valle TT, Hamalainen $\mathrm{H}$, Ilanne-Parikka P, Keinanen-Kiukaanniemi S, Laakso M, Louheranta A, Rastas M, Salminen V \& Uusitupa M (2001) Prevention of type 2 diabetes mellitus by changes in lifestyle among subjects with impaired glucose tolerance. New England Journal of Medicine 344, 1343-1350.

Turpeinen AK, Takala TO, Nuutila P, Axelin T, Luotolahti M, Haaparanta M, Bergman J, Hamalainen H, Iida H, Maki M, Uusitupa MI \& Knuuti J (1999) Impaired free fatty acid uptake in skeletal muscle but not in myocardium in patients 
with impaired glucose tolerance: studies with PET and 14(R,S)-[18F]fluoro-6-thia-heptadecanoic acid. Diabetes 48, $1245-1250$.

van der Vusse GJ, van Bilsen M, Glatz JF, Hasselbaink DM \& Luiken JJ (2002) Critical steps in cellular fatty acid uptake and utilization. Molecular and Cellular Biochemistry 239, $9-15$.

Wade AJ, Marbut MM \& Round JM (1990) Muscle fibre type and aetiology of obesity. Lancet 335, 805-808.

Watt MJ, Stellingwerff T, Heigenhauser GJ \& Spriet LL (2003)

Effects of plasma adrenaline on hormone-sensitive lipase at rest and during moderate exercise in human skeletal muscle. Journal of Physiology 550, 325-332.

Wilmsen HM, Ciaraldi TP, Carter L, Reehman N, Mudaliar SR \& Henry RR (2003) Thiazolidinediones upregulate impaired fatty acid uptake in skeletal muscle of type 2 diabetic subjects. American Journal of Physiology 285, E354-E362.

Zurlo F, Lillioja S, Esposito-Del Puente A, Nyomba BL, Raz I, Saad MF, Swinburn BA, Knowler WC, Bogardus C \& Ravussin E (1990) Low ratio of fat to carbohydrate oxidation as predictor of weight gain: study of 24-h RQ. American Journal of Physiology 259, E650-E657. 